\title{
PERILAKU SEKSUAL PREMARITAL PADA REMAJA DI KOTA SEMARANG
}

\author{
Lia Mulyanti ${ }^{1}$ \\ 1Program Studi S1 Kebidanan Dan Profesi Bidan Universitas Muhammadiyah Semarang Jawa Tengah Email: \\ *Korespondensi email : lia.mulyanti@unimus.ac.id
}

\section{ABSTRACT PREMARITAL SEXUAL BEHAVIOR IN ADOLESCENT IN THE CITY OF SEMARANG}

Background: Adolescents are part of the population aged between 10-19 years in the transition to adulthood. Teenagers have a high curiosity about everything that has never been done. Based on the results of the Indonesian Demographic and Health Survey (IDHS) 2017 shows that 8\% of male adolescents who have had premarital sexual intercourse, of which male adolescents aged 15-19 years are around 3.6\% and aged 20-24 years are around $14.0 \%$. . This figure continues to increase from year to year and must be treated immediately.

Objective: To determine premarital sexual behavior in adolescents

Methods: This study uses a qualitative approach with a case study design to collect in-depth information about how adolescents experience and behave.

Results: Based on the age of the main informants, it was found that they had premarital sexual relations at the age of 14, 15, 16 and 17 years. The main informant's sexual behavior during dating varied from kissing, hugging, touching to having sexual intercourse. After further questioning, the main informants revealed the reasons they wanted to have sexual relations with their last girlfriends because of consensual reasons and because of coercion from their boyfriends as proof of love or as an expression of love.

Conclusion: Based on the results of the study, it can be concluded that premarital sexual behavior in adolescents is mostly carried out by adolescents aged 14-15 years. Sexual behavior is carried out starting from kissing, hugging, touching to having sexual intercourse.

Suggestion Improving life skills in adolescents, especially in assertive skills (being assertive) so that adolescents can express themselves firmly to others without hurting others or humbling themselves in front of others.

Keywords: premarital sexual, adolescent

\section{ABSTRAK}

Latar Belakang: Remaja adalah bagian dari penduduk yang berusia antara 10-19 tahun dalam masa peralihan menuju dewasa. Remaja mempunyai keingintahuan tinggi terhadap segala hal yang belum pernah dilakukannya. Berdasarkan hasil Survei Demografi dan Kesehatan Indonesia (SDKI) 2017 menunjukkan bahwa remaja pria yang pernah melakukan hubungan seksual pranikah sebesar $8 \%$, di mana remaja pria umur 15-19 tahun sekitar 3,6\% dan umur 20-24 tahun sekitar 14,0\%. Angka ini terus meningkat dari tahun ke tahun dan harus segera mendapatkan penanganan.

Tujuan: Untuk mengetahui perilaku seksual premarital pada remaja

Metode: Penelitian ini menggunakan pendekatan kualitatif dengan desain studi kasus untuk mengumpulkan informasi secara mendalam tentang bagaimana pengalaman dan perilaku remaja.

Hasil: Berdasarkan umur dari informan utama diketahui bahwa mereka melakukan hubungan seksual premarital pada saat berusia, 14 tahun, 15 tahun, 16 tahun dan 17 tahun. Perilaku seksual informan utama saat berpacaran bermacam-macam mulai dari ciuman, pelukan, perabaan sampai melakukan hubungan seksual. Setelah ditanya lebih dalam informan utama mengungkapkan alasan mereka mau melakukan hubungan seksual dengan pacar terakhirnya dikarenakan alasan suka sama suka dan karena paksaan dari pacar sebagai pembuktian cinta atau sebagai ungkapan cinta.

Simpulan: Berdasarkan dari hasil penelitian dapat disimpulkan bahwa perilaku seksual premarital pada remaja paling banyak dilakukan oleh remaja berusia 14-15 tahun. Perilaku seksual yang dilakukan mulai dari ciuman, pelukan, perabaan sampai melakukan hubungan seksual.

Saran Meningkatkan kemampuan life skill pada remaja terutama pada keterampilan asertif (bersikap tegas) sehingga remaja dapat mengekpresikan diri secara tegas kepada orang lain tanpa menyakiti pihak ataupun merendahkan diri di hadapan orang lain

Kata Kunci : seksual premarital, remaja 


\section{JKM (Jurnal Kebidanan Malahayati),Vol 7,No.4.Oktober 2021, ISSN (Print) 2476-8944 ISSN (Online) 2579-762X, Hal 836-841}

\section{PENDAHULUAN}

Remaja bisa saja mengatakan bahwa seks bebas atau seks pranikah itu aman untuk dilakukan. Namun, bila remaja melihat dan memahami akibat dari perilaku itu, ternyata lebih banyak membawa kerugian. Salah satu resikonya adalah kehamilan di luar nikah. Merupakan suatu permasalahan kompleks yang dapat menghancurkan segalanya, masa muda, pendidikan, kepercayaan dan kebanggaan orang tua, serta pandangan negatif dari masyarakat (Nirwana, 2011)

Remaja adalah bagian dari penduduk yang berusia antara 10-19 tahun dalam masa peralihan menuju dewasa. Remaja mempunyai keingintahuan tinggi terhadap segala hal yang belum pernah dilakukannya (Kemenkes, 2015)

Remaja merupakan bagian dari masyarakat yang sedang mengalami perubahan fungsi organ tubuh serta fungsi sosial.(Ayu, 2015)

Pada usia ini, remaja memasuki masa produktif dan usia subur artinya remaja secara fisiologis telah mencapai kematangan organ-organ reproduksi, baik remaja laki-laki maupun remaja wanita. Kematangan organ reproduksi mendorong individu untuk melakukan hubungan sosial baik dengan sesama jenis maupun dengan lawan jenis (Tryningtyas, 2017).

Perilaku remaja saat ini cenderung mendekati perilaku yang negatif, tidak memungkiri karena semakin berkembangnya era globalisasi gaya hidup dan perilaku remaja saat ini, di dalam sebuah pergaulan remaja Indonesia sudah tercampur dengan gaya pergaulan dari luar, alhasil banyak kebudayaan ndonesia tidak menjadi tradisi dikalangan remaja, perilaku dianggap sebagai sesuatu yang tidak ditujukan oleh seseorang sehingga dapat disebutan dengan sesuatu tindakan sosial yang amat mendasar oleh sebagian manusia tindakan manusia tidak sama dengan perilaku sosial karena perilaku manusia adalah perilaku yang khusus di tunjukan oleh manusia. Namun tidak semua remaja yang bisa melakukan pergaulan yang negatif namun ada remaja yang mengetahui pergaulan yamg begitu luas namun tidak dilakukan atau dicontoh dalam kehidupannya faktor utama kesalahan dari pergaulan remaja itu bagaimana lingkungan yang ada disekitar individu (Maryati , 2015).

Menurut sebuah penelitian di Amerika Serikat, bahwa sampai dengan usia 25 tahun, sebanyak $88 \%$ remaja perempuan dan $89 \%$ remaja pria pernah melakukan hubungan seks pranikah (Andriani, 2017)

Penelitian Litbang Kesehatan bersama Unesco menunjukan sebanyak $5,6 \%$ remaja
Indonesia sudah melakukan seks pranikah (BKKBN, 2017). Sedangkan menurut hasil Survei Demografi dan Kesehatan Indonesia (SDKI) 2017 menunjukkan bahwa remaja pria yang pernah melakukan hubungan seksual pranikah sebesar $8 \%$, di mana remaja pria umur 15-19 tahun sekitar $3,6 \%$ dan umur $20-24$ tahun sekitar $14,0 \%$. Angka ini terus meningkat dari tahun ke tahun dan harus segera mendapatkan penanganan (Wahyu, 2019) Perilaku seksual pada remaja dipengaruhi oleh berbagai aspek, antara lain teman sebaya, lingkungan sekolah, masyarakat dan aspek sosial budaya. Teman sebaya memiliki peran penting dalam kehidupan sosial dan perkembangan remaja. Beberapa penelitian menunjukkan bahwa teman yang berperilaku negatif cenderung akan memberikan pengaruh negatif bagi remaja (Suparmi, 2016)

Hubungan Seks Pranikah yang dilakukan remaja disebabkan faktor yang berasal dari kematangan seksual di dalam diri remaja yang masih sulit untuk mengendalikan diri terhadap rangsangan seksual sehingga timbul keinginan untuk mengakses situs pornografi ( Sarwono, 2012)

Perilaku seksual di kalangan remaja saat ini memang mengkhawatirkan, tidak sedikit remaja di Indonesia yang memiliki perilaku seksual berisiko khususnya dalam berpacaran. Padahal, banyak dampak buruk dari perilaku seks berisiko tersebut dan cenderung bersifat negatif, diantaranya adalah kehamilan di luar nikah, aborsi, dan infeksi menular seksual. Dampak tersebut tidak saja dirasakan oleh remaja itu sendiri tapi lebih luas akan berdampak negatif bagi keluarga, masyarakat, dan bangsa pada akhirnya (Lestari, 2016)

Dampak perilaku seksual pranikah remaja dapat menimbulkan berbagai dampak negatif pada remaja, diantaranya seperti dampak psikologis (perasaan marah, takut, cemas, depresi, rendah diri, bersalah dan berdosa), dampak fisiologis (menimbulkan kehamilan tidak diinginkan dan aborsi), dampak sosial (dikucilkan, putus sekolah pada remaja perempuan yang hamil, dan perubahan peran menjadi ibu. Belum lagi tekanan dari masyarakat yang mencela dan menolak keadaan tersebut, dan dampak fisik (terkena penyakit seksual dan HIVIAIDS (Ririn,2010).

Selain itu perilaku seksual pranikah pada remaja ini juga akan berdampak pada keadaan ekonomi dan kesejahteraan social dalam jangka panjang tidak hanya berpengaruh pada remaja tersebut tetapi juga terhadap keluarga, masyarakat dan bangsa. Untuk itu perilaku seksual pranikah pada remaja ini perlu mendapat perhatian dari 
berbagai pihak untuk mewujudkan generasi muda yang berkualitas

\section{METODE PENELITIAN}

Penelitian ini menggunakan pendekatan kualitatif dengan desain studi kasus untuk mengumpulkan informasi secara mendalam tentang bagaimana pengalaman dan perilaku remaja tentang seks premarital. Subyek penelitian adalah remaja yang pernah melaukan hubungan seksual pranikah. Kriteria Inklusi pada penelitian ini yaitu remaja yang berstatus belum menikah, sudah pernah melakukan hubungan seksual, berjenis kelamin perempuan dan berdomisili di daerah Kota Semarang. Pada Penelitian ini subyek penelitian berjumlah 7 responden remaja. Teknik pengumpulan data menggunakan wawancara mendalam (Indept Interview) karena untuk mendapatkan keterangan lisan dari seseorang atau subyek penelitian, dengan bercakap-cakap dan berhadapan muka dengan orang tersebut. Dalam melakukan indept interview peneliti dibantu oleh Bidan yang mempunyai pasien remaja dengan kasus KTD. Dalam mengumpulkan data-data peneliti menggunakan 3 alat bantu yaitu pedoman wawancara, catatan lapangan dan alat perekam.

\section{HASIL DAN PEMBAHASAN \\ Karateristik Responden}

Berdasarkan umur dari informan utama diketahui bahwa mereka melakukan hubungan seksual premarital pada saat berusia, 14 tahun, 15 tahun, 16 tahun dan 17 tahun. Berdasarkan kareteristiknya remaja yang telah melakukan hubungan seksual preparital adalah remaja dalam tahap pertengahan (14 sampai 17 tahun). Pada usia remaja awal secara biologis perkembangan hormone seksual dan ciri seksual sekunder mulai tampil bersamaan. Sehingga pada usia ini dorongan seksual sudah mulai kuat terjadi dalam diri remaja. Hal ini yang menimbulkan perilaku seksual yaitu tindakan yang dilakukan atas dasar dorongan seksual antara lain untuk memuaskan hasrat seksual. Hasil studi menyatakan bahwa lebih dari 500 juta usia 10-14 tahun hidup di negara berkembang, dan rata-rata pernah melakukan hubungan seksual pertama kali dibawah usia 15 tahun.

Tabel 1.

\section{Karateristik Informan Utama}

\begin{tabular}{cccc}
\hline Kode informan & Umur & Pertama kali Pacaran & Pendidikan \\
\hline IU1 & 14 tahun & SMP kelas 1 & SMP \\
IU2 & 16 tahun & SMA kelas 2 & SMA \\
IU3 & 16 tahun & SMP kelas 1 & SMA \\
IU4 & 15 tahun & SMP kelas 1 & SMP \\
IU5 & 15 tahun & SMP kelas 2 & SMP \\
IU6 & 14 tahun & SMP kelas 1 & SMP \\
IU7 & 17 tahun & SMP kelas 3 & SMA \\
\hline
\end{tabular}

Hasil penelitian Annesia F (2013) juga menggambarkan bahwa umur juga berhubungan dengan perilaku seks pranikah yaitu sebagian besar responden telah melakukan perilaku seks kategori intim berada pada umur 14 - 15 tahun jika dibandingkan dengan responden umur 13 tahun

Rentang usia informan saat melakukan hubungan seksual adalah 14-17 tahun, dengan usia yang termuda yaitu 14 tahun. Dimana informan masih duduk kelas 2 SMP. Terlalu mudanya informan melakukan hubungan seksual ditakutkan akan berdampak bagi kesehatannya kelak. Usia repoduksi yang sehat yaitu antara 20-35 tahun dimana pada usia tersebut organ reproduksi wanita sudah berkembang dengan sempurna.

Masa remaja diawali oleh masa pubertas yaitu masa terjadinya perubahan-perubahan fisik (meliputi penampilan fisik seperti bentuk tubuh dan proporsi tubuh) dan fungsi fisiologis (kematangan organ-organ seksual). Perubahan tubuh ini disertai dengan perkembangan bertahap dari karateristik seksual primer dan karateristik seksual sekunder (Kusmiran, 2012)

Dilihat dari perkembangan kognitif remaja maka pada masa ini remaja sebenarnya sudah dapat membayangkan suatu rangkaian peristiwa yang mungkin terjadi dan akibatnya. Remaja dengan kemampuan kognitif seperti ini sebenarnya sudah mengetahui beberapa hal yang bisa ditimbulkan dari perilaku seks pranikah yang dilakukannya. Ketika melakukan seks pra nikah, secara logis mereka sebenarnya mengetahui kemungkinan yang akan terjadi. Namun perilaku tersebut tetap dilakukan karena berbagai macam hal, diantaranya memperoleh sensasi yang menyenangkan, memuaskan dorongan seksual, 


\section{JKM (Jurnal Kebidanan Malahayati),Vol 7,No.4.Oktober 2021, \\ ISSN (Print) 2476-8944 ISSN (Online) 2579-762X, Hal 836-841}

memuaskan rasa keingintahuan, sebagai tanda penaklukkan, sebagai ekspresi rasa sayang atau karena mereka tidak mampu untuk menahan tekanan penyesuaian diri dengan kelompok (Kusmiran 2012)

Pada tahap perkembangan remaja rasa ingin tahu mengenai berbagai hal akan timbul dan remaja akan mencoba hal-hal baru yang tidak ia ketahui, selain itu remaja tidak dapat berfikir secara kritis dan terlalu mengedepankan ego serta keingintahuannya tanpa mengerti dampak dan resiko terhadap suatu hal yang akan ia lakukan, jika tidak ada pengawasan dari orang tua dan tidak ada kegiatan yang positif bagi remaja, maka remaja akan terjerumus kepada hal-hal yang negative seperti merokok, minum-minuman beralkohol dan perilaku seks pranikah yang pada akhirnya menimbulkan kerugian bagi remaja itu sendiri, disamping itu kondisi lingkungan sangat berpengaruh terhadap perkembangan remaja, ketika lingkungan bersifat positif maka remaja akan berkembangan kearah yang positif sesuai aturan dan norma yang berlaku begitupun sebaliknya (Setijaningsih et al., 2019)

\section{Pengalaman perilaku seksual reponden}

Pengalaman perilaku seksual informan remaja sangat bervariatif. Saat mereka berpacaran dan melakukan hubungan seksual dengan pacar atau pasangan, mereka tidak memikirkan dampak dari hubungan seksual (intercourse) antara lain aborsi dan kehamilan tidak diinginkan (KTD)

Hasil penelitian didapatkan bahwa 6 informan utama pertama kali mereka pacaran pada saat masih berada dibangku SMP dan 1 informan utama mengatakan pertama kali pacaran pada saat dibangku SMA. Saat di tanya lebih jauh informan utama mengungkapakan kenal dengan pacarnya yang terakhir beraneka ragam yakni kakak kelas SMA, teman les, dikenalin dengan temannya dan tetangga teman. Enam Informan utama mengungkapkan pacarnya yang terakhir bukanlah pacar yang pertama, hanya 1 informan utama yang mengakatakan pacar yang terakhir merupakan pacar yang pertama.

Perilaku seksual informan utama saat berpacaran bermacam-macam mulai dari ciuman, pelukan, perabaan sampai melakukan hubungan seksual.

Seperti yang diungkapkan oleh salah satu responden IU4 yang menyebutkan bahwa:
Kotak 1

Bagaimana Pertama kali melakukan hubungan seksual?

"Awalnya ciuman mbak terus lama kelamaan tangannya kemana-mana mbak terus dia ngajakin ngelakuin gitu-gitu awalnya aku tolak mbak tapi dia maksa terus sampai akhirnya ya tetep ngelakuin gitu mbak"

(wawancara mendalam dengan IU4, 15 tahun)

Setelah ditanya lebih dalam informan utama mengungkapkan alasan mereka mau melakukan hubungan seksual dengan pacar terakhirnya dikarenakan alasan suka sama suka dan karena paksaan dari pacar sebagai pembuktian cinta atau sebagai ungkapan cinta.

Bentuk-bentuk perilaku seksual yang biasa dilakukan adalah (1) kissing atau perilaku berciuman, mulai dari ciuman ringan sampai deep kissing, (2) necking atau perilaku mencium daerah sekitar leher pasangan, (3) petting atau segala bentuk kontak fisik seksual berat tapi tidak termasuk intercourse, baik itu light petting (meraba payudara dan alat kelamin pasangan) atau hard petting (menggosokkan alat kelamin sendiri ke alat kelamin pasangan, baik dengan berbusana atau tanpa busana), dan (4) intercourse atau penetrasi alat kelamin pria ke alat kelamin wanita (Susanti, et al, 2013).

Hasil wawancara mendalam dengan informan utama yang berusia dibawah 15 tahun dari 3 dari 4 informan mengungkapkan melakukan hubungan seksual dengan pacar atau pasangannya didasari perasaan suka sama suka, hanya 1 informan yang mengungkapkan melakukan hubungan seksual dengan pasangannya dikarenakan adanya paksaan dari pacar atau pasangan. Hal ini sama halnya seperti informan yang berusia diatas 15 tahun, dari 3 informan 2 informan melakukan hubungan seksual dengan pacar atau pasangan dengan alasan suka sama suka dan 1 informan yang mengungkapkan melakukan hubungan seksual dikarenakan adanya paksaan dari pacar atau pasangan.

Seperti yang diungkapkan oleh salah satu responden IU4 yang menyebutkan bahwa: 
Kotak 2

Apakah alasan anda melakukan hubungan seksual?

“...pertamanya aku gak mau mbak terus pacarku maksa mbak katanya kalau gak mau gak cinta katanya.. terus ya udah akhirnya aku mau mbak terus akhirnya ya kejadian ngelakuin gitu"

(wawancara mendalam dengan IU3, 16 tahun)

Masa pacaran bagi remaja adalah saat untuk dapat memberikan kasih sayangnya kepada orang lain secara nyata.

Perilaku seksual sering ditanggapi sebagai hal yang berkonotasi negative, padahal perilaku seksual ini sangat luas sifatnya. Perilaku seksual merupakan perilaku yang bertujuan untuk menarik perhatian lawan jenis. Aktifitas seksual adalah kegiatan yang dilakukan dalam upaya memenuhi dorongan seksual atau kegiatan mendapatkan kesenangan organ kelamin atau seksual melalui berbagai perilaku (Kusmiran, 2012)

Penelitian yang dilakukan oleh Ningtyas meyebutkan bahwa terjadinya perilaku seksual pada remaja salah satunya dipengaruhi oleh perubahan pandangan yang tampak saat remaja mulai memasuki masa pacaran. Masa pacaran telah diartikan menjadi masa untuk belajar melakukan aktivitas seksual dengan lawan jenis, mulai dari ciuman ringan, ciuman maut, saling masturbasi, seks oral, bahkan sampai hubungan seksual (Ningtyas, 2012)

Hal ini sejalan dengan penelitian Mukaromah menyatakan bahwa terdapat empat siswa mengatakan pernah melakukan hubungan seksual dengan pacarnya, siswa mengatakan alasan melakukan hubungan seksual karena tidak dapat mengontrol diri saat bertemu dengan pacarnya (Mukaromah et al., 2013). Hal ini menggambarkan bahwa kedekatan remaja dengan pacar dapat mendorong remaja ke dalam perilaku seks pranikah.

Hasil wawancara dengan informan utama didapatkan bahwa dari tujuh informan utama 3 informan utama menjawab melakukan hubungan seksual di rumah baik dirumahnya sendiri atau dirumah pasangannya, 2 informan utama menjawab di kost pacar atau pasangannya, dan 2 informan utama menjawab telah melakukan hubungan seksual di hotel.

Seperti yang diungkapkan oleh salah satu responden IU4 yang menyebutkan bahwa:

\section{Kotak 3}

Dimana anda melakukan hubungan seksual?

"... Pas pertama kali ngelakuin gitu di rumahnya cowokku mbak, pas diajakin kesana pas rumahnya sepi,.."

(wawancara mendalam dengan IU1, 14 tahun)

Keadaan rumah yang sepi menyebabkan remaja dapat melakukan apa saja tanpa pengawasan dari orang tua. Selain dirumah beberapa informan juga menyebutkan jika mereka pertama kali melakukan hubungan seksual di kost pasangannya.

Tempat kost yang bebas tanpa pengawasan dari ibu kost hal ini juga dapat menyebabkan memudahkan anak kost untuk melakukan apa saja terutama hubungan seksual. Hal ini seperti yang diungkapkan oleh IU2 yang menjelaskan bahwa saat pertama kali melakukan hubungan seksual dengan pacar atau pasangannya yaitu di tempat kost pacarnya. Dimana tempat kost dari pacarnya tersebut adalah kost yang campur antara perempuan dan laki-laki. Hal ini menyebabkan mudahnya akses untuk masuk ke dalam kost tersebut. Minimnya pengawasan dari pemilik kost juga mempermudah anak kost melakukan berbagai macam hal terutama berhubungan seksual.

\section{SIMPULAN}

Berdasarkan dari hasil penelitian dapat disimpulkan bahwa perilaku seksual premarital pada remaja paling banyak dilakukan oleh remaja berusia 14-15 tahun. Perilaku seksual yang dilakukan mulai dari ciuman, pelukan, perabaan sampai melakukan hubungan seksual.

\section{SARAN}

Meningkatkan kemampuan life skill pada remaja terutama pada keterampilan asertif (bersikap tegas) sehingga remaja dapat mengekpresikan diri secara tegas kepada orang lain tanpa menyakiti pihak ataupun merendahkan diri di hadapan orang lain

\section{DAFTAR PUSTAKA}

Andriyani, Maududi AA Al. 2018. Peran teman sebaya terhadap perilaku seksual siswa SMA X Jakarta. J Kedokt dan Kesehat. 2018;14(2).

Ayu Khoirotul U, Kusumawati Y, Kasjono HS. 2015. Hubungan antara faktor internal dan faktor eksternal dengan perilaku seksual pranikah 
remaja di Indonesia. J Kesehat Masy Andalas. 2015;10(1):65-75.

BKKBN. 2017. Survei Demografi dan Kesehatan Indonesia. Administrator SDKI.

Kusmiran, Eni. 2012. Kesehatan Reproduksi Remaja dan Wanita. Jakarta : Salemba Medika.

Lestari, S. 2016. Psikologi Keluarga. Jakarta: Prenadamedia Group

Mukaromah, F., Livana, P., \& Susanti, Y. 2013. Hubungan Karakteristik Remaja, Keluarga Dan Pola Asuh Orangtua Dengan Perilaku Seksual Remaja. Jurnal IImiah Permas: Jurnal IImiah STIKES Kendal, 3(2), 36-44.

Ningtyas, S. D. Y. 2012. Hubungan antara Self Control dengan Internet Addiction pada Mahasiswa. Educational Psychology Journal, 1(1), 25-30

Nirwana, Benih Ade. 2011. Psikologi Kesehatan Wanita.Yogyakarta: Nuha Medika

Ririn, 2010. Dampak Perilaku Seks Pranikah Melalui di akses pada tanggal 7 Juli 2021
Sarwono, wirawan Sarlito, 2012. Psikologi Remaja : Definisi Remaja, Jakarta : Rajagrafindo Persada

Setijaningsih, T., Hasanudin, H., \& Winarni, S. 2019. Persepsi antara Remaja yang Berpacaran dengan Remaja yang Tidak Berpacaran tentang Perilaku Seks Pranikah. Journal of Borneo Holistic Heatlh, 2(1), 1-16

Suparmi S, Isfandari S. 2016. Peran teman sebaya terhadap perilaku seksual pranikah pada remaja laki-Laki dan perempuan di Indonesia. Bul Penelit Kesehat. 2016;44(2):139-46.

Susanti, S., Setyowati, E., Nanik, Rr. 2013. Persepsi Siswa Kelas XI SMK Negeri 4 Surabaya terhadap Perilaku Seks Bebas dikalangan Pelajar Surabaya. IPI, 3 (1): 2

Tryningtias, D.A 2017. Sex Education. Edisi 1. CV Ae Media Grafika.

Wahyuni S, Fahmi I. 2019. Determinan perilaku seksual pra nikah remaja pria di Indonesia hasil SDKI. Euclid. 2019;6(2):177. 